\title{
The complex researches of an Alosol from Romania
}

\author{
Alexandrina Manea ${ }^{1}$, Daniela Răducu ${ }^{1}$, Rodica Lazăr ${ }^{1}$, Monica Dumitrașcu ${ }^{1}$, Alina Eftene ${ }^{1}$ \\ ${ }^{1}$ National Research and Development Institute for Soil Science, Agrochemistry and Environment, \\ Bucharest, Romania
}

To cite this article: Manea, A., Răducu, D., Lazăr, R., Dumitrașcu, M. \& Eftene, A. (2017). The complex researches of an Alosol from Romania. Lucrările Seminarului Geografic Dimitrie Cantemir, Vol. 45, pp. 215-219. DOI: 10.15551/lsgdc.v45i0.18

To link to this article: http://dx.doi.org/10.15551/lsgdc.v45i0.18 


\title{
THE COMPLEX RESEARCHES OF AN ALOSOL FROM ROMANIA
}

\author{
Alexandrina Manea ${ }^{1}$, Daniela Răducu ${ }^{1}$, Rodica Lazăr ${ }^{1}$, \\ Monica Dumitrașcu', Alina Eftene ${ }^{1}$
}

\begin{abstract}
Le but de cet article est d'identifier les caractéristiques spécifiques d'un Alosol au moyen des propriétés morphologiques (lors des études expéditionnaires sur le terrain) et des données analytiques chimiques, physiques et micromorphologiques. Le site étudié est situé dans la partie de sud-est des Montagnes Apuseni, dans la Dépression Zlatna, sur une pente $\geq 25 \%$, orientée vers le nord. Le sol est un Alosol formé dans des dépôts de pente ayant texture limoneuse et gravier constitués de fragments de grès $(10$ à $15 \%)$. Au cours des études expéditionnaires sur le terrain, la morphologie du sol révèle une différenciation texturale à cause d'une teneur élevé en argile dans le sous-sol où s'est formé l'horizon Bt argic. Les données analytiques ont montré que la teneur en argile est de 17,8 - 23,4\% au sommet du profile, dans l'horizon A, tandis qu'en profondeur, dans l'horizon Bt, l'argile atteindre 21,36 - 30,42\%. Dans ces conditions, l'indice de différenciation texturale (argile $\mathrm{B} /$ argile A) est 1,2 - 1,3, classifiant l'horizon B à l'horizon ,argice (Bt) et le sol dans la classe „Luvisol ${ }^{e}$. Selon les caractéristiques chimiques (très forte acidité et debazification sévère associée à

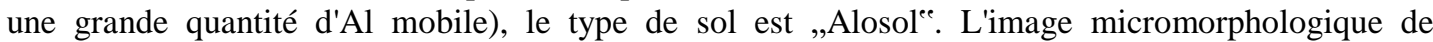
l'horizon $\mathrm{Bt}$ ne reflète pas ni les caractéristiques chimiques du profil ( $\mathrm{pH}$ acide et teneur élevée en $\mathrm{Al}$ ), ni l'agressivité de la solution du sol, ou la destruction des minéraux argileux. L'observation micromorphologique a mis en évidence les caractéristiques propres à une «couche d'altération» (à cause de la forte altération des roches et, en conséquence, à une forte argilisation in situ). En conclusion, les résultats de l'étude montre que du point de vue chimique, le sol est plus développé et plus ancien, tandis que du point de vue micromorphologique, le sol est plus jeune (en raison de l'apport continu de constituants résultant de l'altération: argile, Fe, etc.).
\end{abstract}

Keywords: Alosol, micromorphology, saprolites, weathering, lessivage

\section{Introduction}

In the Romanian classification (SRTS-2012), Alosols are defined as ,soils having an ochric or umbric horizon (Ao or $\mathrm{Au}$ ) followed directly or after an eluvial horizon (E), by a B $\operatorname{argic}(\mathrm{Bt})$ horizon having a value of the clay cation exchange capacity of $24 \mathrm{me} / 100 \mathrm{~g}$ or greater and a value of the base saturation $<53 \%$ at least in the upper part of the Bt horizon until $100 \mathrm{~cm}$ or until $\mathrm{R}$ or $\mathrm{C}$ horizon if it appear up to $100 \mathrm{~cm}^{\mathrm{ee}}$.

According to WRB-SR - 2014 these soils are Alisols and define a soil group having ,an argic horizon (starting $\leq 100 \mathrm{~cm}$ from the soil surface); and, a base saturation, calculated on the sum of exchangeable bases (by $1 M$ NH4OAc, pH 7) plus exchangeable Al (by $1 M$ $\mathrm{KCl}$, un-buffered), of <50\%: a. in the major part between 50 and $100 \mathrm{~cm}$ from the mineral

\footnotetext{
${ }^{1}$ National Research and Development Institute for Soil Science, Agrochemistry and Environment ICPA Bucharest, 61 Mărăşti, 011464, sector 1, Bucureşti, Romania, daniela.icpa@yahoo.com.
} 
soil surface; or $\mathrm{b}$. in the lower half of the mineral soil above continuous rock, technic hard material or a cemented or indurated layer starting $\leq 100 \mathrm{~cm}$ from the mineral soil surface e.

Thus, Alisols have a dense subsurface clay layer, which causes a relatively high concentration of aluminum ions in the root zone, and a specific cation exchange capacity.

In many soils located on slopes, the presence of a more clayey layer in the lower part (or at the bottom) of the soil profile could be considered either a B argic (Bt) horizon, or a clayey layer (also known as „bad of alteration“e or ,alteration bad ${ }^{\text {ee }}$ ).

The ,alteration bad ${ }^{\text {ee }}$ is a mineral layer, representing a young deposit with fine texture formed at the bottom of the soil profile, resulting from rock alteration, in which there are locally preserved both the rock structure, and the deep weathered rock fragments, very friable and containing redoximorphic features; it could be confounded with $\mathrm{B}$ ( $\mathrm{Bv}$ or $\mathrm{Bt}$ ) horizon (Răducu, 2015).

In the soil science literature, this clayey layer is defined as ,saprolite ${ }^{c e}$, which is chemically weathered rocks and form in the lower zones of the soil profiles, representing deep weathering of the bedrock surface. Saprolite (from Greek $=$ putrid + rock) is a chemically weathered rock (literally, it means ,,rotten rock ${ }^{e c}$ ).

The identification of the boundary between soil and saprolite is a complex task due to the diversity of processes that modify the transition from rock to soil (Stolt and Baker, 1994). When saprolite maintains a rock structure, it is denominated " $\mathrm{Cr}$ ".

Pedron et al. (2015) evaluating six Alisol profiles, showed that the sequence of horizons found was $\mathrm{A}, \mathrm{Bt}, \mathrm{C}$, and $\mathrm{Cr}$, where $\mathrm{C}$ was considered part of the soil due to its pedogenetic structure, and $\mathrm{Cr}$ was considered saprolite due to its rock structure. The morphological properties that were determined in the field and that were different between the $\mathrm{B}$ and $\mathrm{C}$ horizons and the $\mathrm{Cr}$ layer were color, structure, texture, and fragments of saprolite. According to the test of means, the properties that support the inclusion of the $\mathrm{C}$ horizon as part of the soil are sand, clay, water-dispersible clay, silt/clay ratio, macroporosity, total porosity, resistance to penetration, cation exchange capacity, $\mathrm{Fe}$ extracted by $\mathrm{DCB}, \mathrm{Al}, \mathrm{H}+\mathrm{Al}$, and cation exchange capacity of clay. The properties that support the $\mathrm{C}$ horizon as a transition zone are silt, $\mathrm{Ca}$, total organic $\mathrm{C}$, and $\mathrm{Fe}$ extracted by ammonium oxalate. Discriminated analysis indicated differences among the three horizons evaluated.

Quénard et al. (2011) showed that lessivage consists of a substantial vertical transfer of fine particles from an eluvial E-horizon to an illuvial B-11 horizon. It has been described as a major or secondary pedogenetic process for many soil types. However, lessivage fluxes have never been measured because of obvious technical difficulties; thus, lessivage has been poorly quantified, if at all, and has rarely been modelled. For those reasons, the existence of lessivage is somewhat controversial. According to our mass balance calculation, lessivage, classically described as a major soil forming process in Albeluvisols and Luvisols, is actually responsible for the formation of only $1 \%$ to $12 \%$ of the Luvisol and Albeluvisol profiles reported in the French soil database (DoneSol). In the remaining cases, lessivage may or may not be a secondary process of soil evolution that occurs along with a change in parent material, bioturbation or chemical weathering. While our approach allows us to determine if this process is the main process responsible for soil formation, it does not allow us to rule out its occurrence as a secondary or accessory process in the soil. 
The aim of the paper is to identify the specific characteristics of an Alosol by the aim of the morphological properties (during the expeditionary studies in the field) corroborated with the chemical, physical and micromorphological analytical data.

\section{Material and methods}

The studied site is located in the south-eastern part of Apuseni Mountains, in Zlatna Depression, on a slope $\geq 25 \%$, facing north. The soil is Alosol (belonging to the Luvisol class - according to SRTS-2012) formed in slope deposits (of 3 - $4 \mathrm{~m}$ thick) having loamy texture and being moderately gravelly $(10-15 \%$ sandstones). The average annual temperature is of $8^{\circ} \mathrm{C}$ and the average annual rainfall is $630 \mathrm{~mm}$. The water table is at > 10 m.

In Zlatna area, because of Ampellum S.A activity, the emissions of dioxide and trioxide sulfur caused acid precipitation in the area, which affected the soil physical, chemical and biologic properties. Thus, soil acidification and debazification are more anthropic than natural. Disturbed (for physical and chemical analysis) and undisturbed (for micromorphological study) soil were sampled and determined by the standard methods of ICPA-Bucharest (ICPA Methodology- 1987).

The $\mathrm{pH}$ was determined by the potentiometric method (in water suspension - 1:2,5). The exchangeable aluminum $\left(\mathrm{Al}^{3+}\right)$ was determined by Sokolov method. The degree of base saturation $\left(\mathrm{V}_{8,3}, \%\right)$ and the total cationic exchange capacity $\left(\mathrm{T}_{8,3}=\mathrm{EB}+\mathrm{A}_{8,3}\right)$ were determined by calculation, while the sum of exchangeable bases (EB, me/100 $\mathrm{g}$ soil) and the hydrolytic acidity (HA) were determined by Kappen method.

The micromorphological undisturbed samples were air drayed and impregnated with epoxidic resins. After hardening, oriented thin sections $(25-30 \mu \mathrm{m})$ have been made from each sample and studied after words with Documator $(20 \mathrm{X})$ and optical microscope (50-100 $\mathrm{X}$ ) in PPL and XPL. The terminology used for micromorphological description was according to Bullock et al. (1985).

\section{Results and discussions}

During the expeditionary studies in the field, the soil morphology revels a textural differentiation due to higher clay content in the subsoil where $\mathrm{Bt}$ argic horizon was formed.

The analytical data showed that the clay content is $17.8-23.4 \%$ in the surface A horizon, while in the Bt sub-horizons it is $21.36-30.42 \%$. In these conditions, the textural differentiation index (clay from B horizon / clay from A horizon) is $1.2-1.3$, which assign the B horizon to ,argice (Bt) and the soil to the „Luvisole ${ }^{\text {ee }}$ class (according to SRTS-2012).

The soil has a very high acidity $(\mathrm{pH}$ is $3.92-4.62)$ and a severe debazification (base saturation being $0.78-6.32 \mathrm{me} / 100 \mathrm{~g}$ soil) which is associated with a high amount of $\mathrm{Al}$ $(1.53-4.43 \mathrm{me} / 100 \mathrm{~g}$ soil) until $90 \mathrm{~cm}$ deep (Figure 1). The soil has a very unfavorable trophic regime for the plant development. 


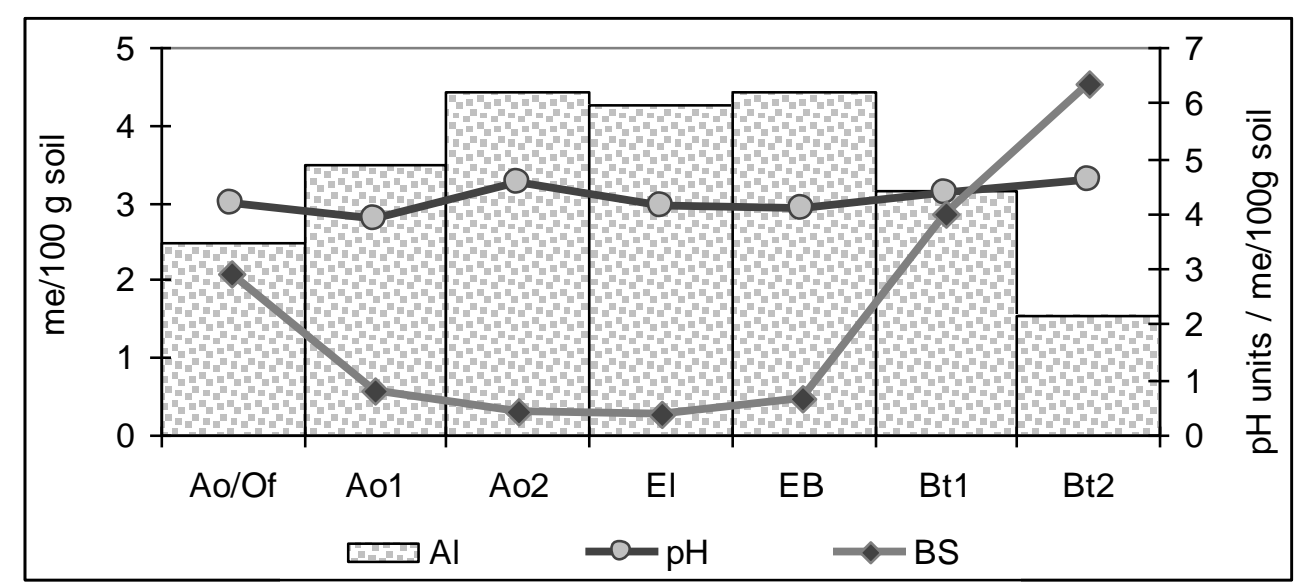

Figure 1. The base saturation and the Al content associated with the low $\mathrm{pH}$ of the studied soil

According to the chemical characteristics, the soil type is Alosol.

The micromorphological observation on soil thin sections pointed out that plasmic fabric (spatial organization of plasmic constituents $<2 \mu \mathrm{m}$ ) within the matrix of the upper $\mathrm{Ao}_{2}$ horizon $(7-25 \mathrm{~cm})$ is specific to the horizons with low $\mathrm{pH}$ and with organic matter resulting from the decomposition of the vegetal remains of the acidophilic species) combined with significant amounts of $\mathrm{Fe}$ and $\mathrm{Al}$.

In the $\mathrm{EB}(40-62 \mathrm{~cm})$ and the $\mathrm{Bt}(62-112 \mathrm{~cm})$ horizons, the elementary fabric (spatial organization of plasma and skeleton grains) is specific to the horizons with strong alteration of the skeleton grains, where the weathering products (clay, Fe etc.) appear: on the surfaces of the rock fragments; embedded in the soil matrix and preserving the rock structure (in the case of highly or totally alteration of the minerals composing rock fragments); or locally translocated into the soil matrix (within the immediate vicinity of the rocks) and having a fluid appearance.

The $\mathrm{Bt}_{2}(90-112 \mathrm{~cm})$ horizon is enriched in situ with large amounts of clay resulting from weathering, which gives it the characteristics of a horizon known as ,alteration bed ${ }^{\text {ee }}$. It is a young horizon due to the presence of the rock fragments (dominated by ferruginous sandstones) strongly weathered, which continuously supply and enrich the horizon matrix with weathering products (plasmic elements as clay, Fe, Al, etc.).

For this reason, the micromorphological image of the $\mathrm{Bt}_{2}$ horizon does not reflect the chemical characteristics (acid $\mathrm{pH}$ and high $\mathrm{Al}$ content), as it does not reflect the aggressiveness of the soil solution or the destruction of the clay minerals. This aspect can only be explained by the strong alteration of the skeleton grains which provide elements that hide (and/or buffers) the destruction and the translocation of soil plasma.

Prioritizing the processes that lead to the studied soil pedogenesis, the alteration (in situ argilization) could be put in the foreground, followed by the clay translocation. More specific: in the foreground are the processes that lead to the formation of an ,alteration bad (intense chemical weathering), followed by the process that lead to the B argic horizon formation (clay translocation or lessivage). The clay translocation is inevitable in the conditions of: a very large amount of clay resulting from weathering; climatic conditions specific to the area; as well as the soil profile location on a slope $\geq 25 \%$. 


\section{Conclusions}

The following conclusions can be drawn:

- The textual differentiation index (clay from B/clay from A) being 1.2 - 1.3, assigned the B horizon to , $\operatorname{argic}^{\text {"e }}(\mathrm{Bt})$, and the soil to „Luvisol ${ }^{\text {ee }}$ class.

- The soil has Alosol characteristics, according to the chemical properties: very high acidity, as well as the severe debazification associated with a large amount of Al.

- The micromorphological image of the $\mathrm{Bt}_{2}$ horizon:

did not reflect the chemical characteristics (low $\mathrm{pH}$ and high $\mathrm{Al}$ content), or the aggressiveness of the soil solution that induce the destruction of clay minerals (due to the richness of the rock fragments which, by alteration, provide elements that hide or buffer the destruction and the translocation of soil plasma).

showed the characteristics specific to the ,,alteration bad ${ }^{\text {ee }}$.

- From the chemical point of view, the soil is more developed and older, while from the micromorphological point of view, the soil is younger (due to the continuous supply with weathering products: clay, Fe, etc.).

\section{Acknowledgments}

The researchers were performed within the projects: PN 16070105 „Utilizarea tehnicii micromorfologice în studiul biodiversităţii din solurile agricole - suport pentru serviciile ecosistemice produse de sol” (,The utilization of micromorphological techniques in the study of the biodiversity from agricultural soils - support for the ecosystem services provide by soil").

\section{References}

1. Bullock P., Fedoroff N., Jongerius A., Stoops G., Tursina T., Babel U., 1985. Handbook for soil thin section description. Wine Research Publication: $152 \mathrm{pp}$.

2. Florea N., Munteanu I., 2012. Sistemul român de taxonomia solurilor (SRTS-2012). Editura Estrafia, Bucureşti, Romania: 206 pp.

3. Quénard L., Samouëlian A., Laroche B., Cornu S., 2011. Lessivage as a major process of soil formation: a revisitation of existent data. Geoderma, vol. 167-168:135-147.

4. Pedron F.A., Oliveira R.B., Dalmolin R.S.D., Azevedo A.C., Kilca R.V., 2015. Boundary between Soil and Saprolite in Alisols in the South of Brazil. Revista Brasileira de Ciência do Solo, vol.39, n.3: 643-653.

5. Răducu D., 2015. Îndreptar de Teren pentru Diagnosticarea, clasificarea și descrierea morfologică a solurilor. Editura Fundației România de Mâine, București: 211 pp.

6. Stolt M.H., Baker J.C., 1994. Strategies for studying saprolite and saprolite genesis. In: D.L. Cremeens, R.B. Brown, J.H. Huddleston (Eds) Whole regolith pedology. Madison: Soil Science Society of America, Special publication, nr. 34: 1-20.

7.WRB-SR - 2014. IUSS Working Group WRB. World reference base for soil resources. International soil classification system for naming soil and creating legends for soil maps. Rome: FAO; (World Soil Resources Report, 103). 